\title{
Efektifitas Klaster Tanaman Sebagai Penghalang Alami Tingkat Kebisingan Kendaraan Bermotor di Jalan By Pass Alang-Alang Lebar Kota Palembang
}

\author{
Jumingin $^{(1)^{*}}, \operatorname{Atina}^{(1)}$ \\ ${ }^{(1)}$ Program Studi Fisika, Fakultas MIPA Universitas PGRI Palembang, Palembang 30251 \\ ${ }^{(1)}$ Program Studi Fisika, Fakultas MIPA Universitas PGRI Palembang, Palembang 30251 \\ "e-mail : juminginpgri@gmail.com, atina.salsabila@gmail.com
}

\begin{abstract}
Abstrak
Telah dilakukan penelitian tentang efektifitas klaster tanaman sebagai penghalang alami tingkat kebisingan kendaraan bermotor di Jalan By Pass Alang-Alang Lebar Kota Palembang. Tujuan dari penelitian ini adalah menemukan dan menganalisis klaster tanaman yang paling efektif di sepanjang Jalan By Pass Alang-Alang Lebar Kota Palembang sebagai penghalang alami untuk mereduksi tingkat kebisingan. Alat yang digunakan dalam penelitian ini sound level meter (SLM) tipe Luxtron Sl-4010, roll meter $(50 \mathrm{~m})$, tripod, dan stopwatch. Penelitian ini dilakukan dengan pengukuran langsung di lapangan, menggunakan metode purpossive sampling sesuai dengan klaster tanaman yang ada di lokasi penelitian. Sound level meter pertama diletakkan di depan klaster tanaman (1 meter dari pinggir jalan) dan sound level meter kedua diletakkan di belakang klaster tanaman (5 meter dari klaster tanaman). Untuk mendapatkan tingkat kebisingan pada aktifitas siang hari, pengukuran dilakukan pada pukul $07.00 \mathrm{WIB}, 10.00$ WIB, 15.00 WIB, dan 20.00 WIB pada masing-masing titik pengukuran selama 10 menit dengan pembacaan setiap 5 detik. Dari hasil penelitian ditemukan bahwa klaster tanaman bunga tanjung memiliki efektifitas sebagai penghalang alami tingkat kebisingan dibandingkan dengan klaster tanaman yang ada di lokasi penelitian seperti bungur, tembesi, mahoni, dan palem. Dari analisis sidik ragam yang dilakukan menunjukkan bahwa reduksi tingkat kebisingan oleh klaster tanaman bunga tanjung berbeda nyata dengan klaster tanaman mahoni, dengan sigfikansi 0,039.
\end{abstract}

Kata kunci: By Pass, Kebisingan, Klaster tanaman, Reduksi

\section{Effectiveness of Plant Clusters as Natural Barriers to the Level of Motor Vehicle Noise on the By Pass Alang-Alang Lebar Road in Palembang}

\begin{abstract}
Research has been conducted on the effectiveness of plant clusters as a natural barrier to the level of motor vehicle noise on the By Pass Alang-Alang Lebar Road in Palembang. The purpose of this study is to find and analyze the most effective plant clusters along on By Pass Alang-Alang Lebar street Palembang City as a natural barrier to reduce noise levels. The instrument used in this study is the Luxtron Sl-4010 type of sound level meter (SLM), roll meter $(50 \mathrm{~m})$, tripod, and stopwatch. This research was conducted by direct measurement in the field, using purposive sampling method in accordance with existing plant clusters at the study site. The first sound level meter is placed in front of the plant cluster (1 meter from the roadside) and the second sound level meter is placed behind the plant cluster ( 5 meters from the plant cluster). To obtain noise levels in daytime activities, measurements were made at $07.00 \mathrm{WIB}, 10.00 \mathrm{WIB}$, $15.00 \mathrm{WIB}$, and $20.00 \mathrm{WIB}$ at each measurement point for 10 minutes with readings every 5 seconds. From the results of the study found that the bunga tanjung plant cluster has effectiveness as a natural barrier of noise level compared to the existing cluster of plants in the study location such as bungur, Tembesi, magahoni and palm. From the analysis of variance
\end{abstract}


conducted showed that the reduction of noise level by the cluster of bunga tanjung plants was significantly different from the cluster of magahoni plants, with a significance of 0.039 .

Keywords: By Pass, Noise, Plant Cluster, Reduction

\section{PENDAHULUAN}

Pembangunan fly over disimpang bandara SMB II Palembang telah dilaksanakan dalam dua tahun terakhir dan telah dilakukan finishing. Adanya fly over ini dapat memperlancar arus lalulintas, tetapi kendaraan berat dari arah Jalan Kol. H. Burlian menuju Jalan Palembang-Jambi dan sebaliknya tidak boleh melintas di atas fly over tersebut. Kendaraan-kendaraan berat tersebut harus melalui jalan By Pass Alang-Alang Lebar Palembang. Disamping kendaraan berat tersebut, banyak juga kendaraan bermotor lain baik dari arah Palembang menuju ke Kabupaten Banyuasin, Sekayu, Propinsi Jambi dan Propinsi lainnya maupun sebaliknya yang melintas di Jalan By Pass Alangalang Lebar kota Palembang. Akibatnya aktivitas kendaraan yang melalui jalan By Pass tersebut mengalami peningkatan dari biasanya dalam dua tahun terakhir.

Adanya peningkatan aktivitas kendaraan bermotor (perkembangan jumlah, volume lalu lintas dan sarana transportasi) baik kendaraan ringan ataupun kendaraan berat di jalan tersebut jelas mempunyai dampak terhadap lingkungan sekitar, baik dampak positif maupun dampak negatif. Salah satu dampak negatif yang ditimbulkan misalnya adanya peningkatan kebisingan yang dihasilkan. Adanya kepadatan jumlah kendaraan mempengaruhi tingkat kebisingan di jalan raya (Setiawan, 2014). Peningkatan volume lalu lintas sangat berpengaruh terhadap kebisingan (Wardika dkk, 2012). Adanya penambahan volume lalu lintas di ruas jalan Slamet Riyadi Kota Surakarta, menyebabkan terjadinya peningkatan kebisingan di jalan tersebut (Nurmaningsih dkk, 2014).

Peningkatan kebisingan yang terjadi dapat dikurangi atau dikendalikan dengan cara usaha pengendalian pada media perambatan bunyi, misalnya dengan cara membuat penghalang yang berada diantara sumber dan penerima (lingkungan). Penghalang kebisingan dapat berupa penghalang alami dengan menggunakan pepohonan atau vegetasi tanaman yang ditanam di pinggir jalan raya. Menurut Satoto (2018), Penghalang (Barrier) tingkat kebisingan dapat berupa Barrier alami (tanaman atau gundukan tanah) dan Barrier buatan (berupa bahan yang rapat dan tak bercelah).

Penggunaan model arsitektur pohon seperti bambu (model McClure), bungur (model Troll), dan mahoni (model Rauh) di sepanjang jalan Demang Lebar Daun Palembang sebagai pereduksi kebisingan, menghasilkan reduksi yang berbeda (Jumingin dkk, 2016). Penggunaan pohon penghalang atau Green Barrier seperti perdu atau pohon cemara mampu mengurangi tingkat polusi suara (Cobani dan Aleksi, 2012). Penggunaan pagar hidup yang cukup rimbun dan tinggi dapat dijadikan sebagai filter untuk meredam kebisingan dari lalu lintas kendaraan bermotor (Werdiningsih, 2007). Perencanaan dan penggunaan vegetasi di pinggir jalan dapat mengurangi kebisingan jalan raya (Kalansuriya dkk, 2009).

Di sepanjang pinggir jalan By Pass Alang-alang Lebar sendiri telah ditanami berbagai jenis tanaman, dibagian titik tertentu tanaman tersebut ditanam dalam bentuk klaster dengan jenis tertentu yang memanjang dengan panjang tertentu. Sehingga diharapkan 
dengan adanya penanaman berbagai jenis tanaman di pinggir jalan yang berbentuk tersebut, mampu memberikan fungsi yang ramah lingkungan dalam mengatasi munculnya kebisingan. Memang telah banyak dilakukan berbagai penelitian untuk mengurangi dampak dari kebisingan, namun peneliti tertarik untuk melakukan penelitian apakah sistem klaster tanaman di jalan By Pass Alangalang Lebar Palembang akan memberikan sumbangsih yang efektif dalam menurunkan kebisingan.

Tujuan dari penelitian ini adalah menemukan dan menganalisis klaster tanaman yang paling efektif di sepanjang Jalan By Pass Alang-Alang Lebar Kota Palembang sebagai penghalang alami untuk mereduksi tingkat kebisingan.

\section{BAHAN DAN METODE}

Penelitian ini akan dilaksanakan di Jalan By Pass Alang-Alang Lebar Kecamatan Alang-Alang Lebar Kota Palembang Propinsi Sumatera Selatan, mulai dari simpang lampu merah Jalan Soekarno-Hatta sampai Simpang Tiga Jalan Palembang-Jambi. Peta lokasi penelitian disajikan pada gambar 1 berikut:

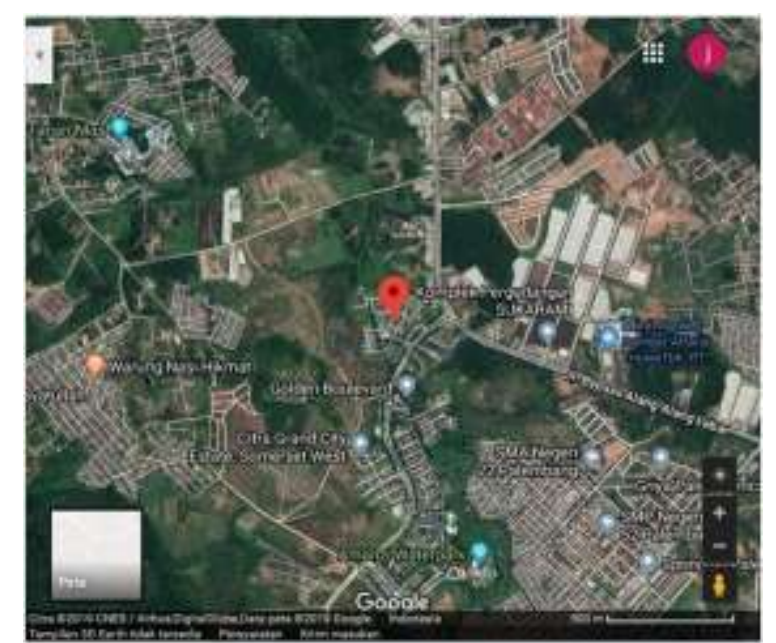

Gambar 1. Peta Jalan By Pass Alang-Alang Lebar Kota Palembang

Alat-alat yang digunakan dalam penelitian ini adalah sounlevel meter (SLM) tipe Luxtron SL-4010, roll meter $(50 \mathrm{~m})$, tripod, dan stopwatch. Metode yang digunakan dalam penelitian ini adalah purpossive sampling sesuai dengan klaster tanaman yang ada di lokasi penelitian, terdiri dari 2 (dua) tahapan yaitu survey pendahuluan dan pengukuran tingkat kebisingan.

Secara garis besar prosedur penelitian ditunjukan oleh diagram alir penelitian pada gambar 2 berikut: 


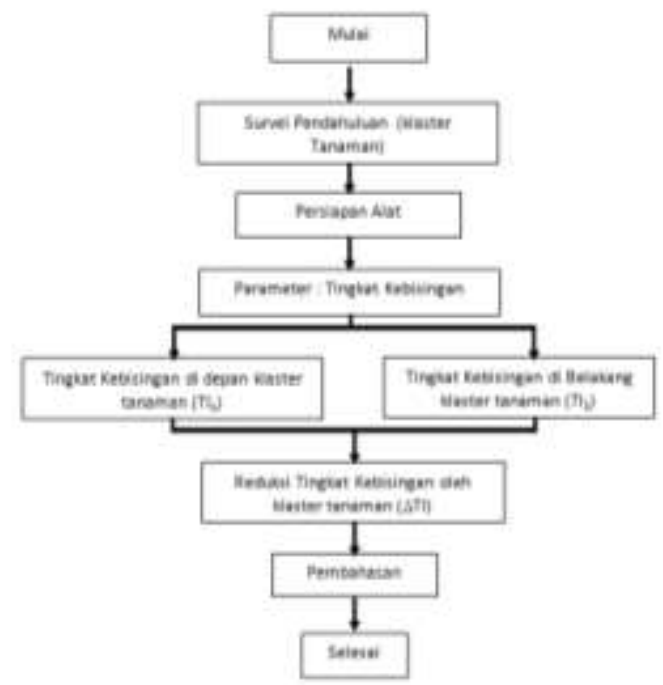

Gambar 2. Diagram alir penelitian

Survey pendahuluan dilakukan untuk mengetahui klaster tanaman (nama pohon dalam setiap klaster tersebut) dan panjang klaster tanaman. Sedangkan pengukuran tingkat kebisingan kendaraan bermotor, dilakukan pada titik di depan (1 meter dari pinggir jalan) dan di belakang klaster tanaman (5 meter dari klaster tanaman). Pengukuran tingkat kebisingan dilakukan pada aktivitas siang hari (yaitu pukul 07.00 WIB, 10.00 WIB, $15.00 \mathrm{WIB}$ dan $20.00 \mathrm{WIB})$ selama 30 hari, lama pengukuran selama 10 menit dengan pembacaan setiap 5 detik di tiap titik pengukuran (Jumingin dkk, 2016 dan KepmenLH, 1996). Sound level meter pertama diletakkan 1 meter dari pinggir jalan dan sound level meter kedua diletakkan $5 \mathrm{~m}$ di belakang klaster tanaman serta berada $1,5 \mathrm{~m}$ diatas permukaan tanah (Tyagi dkk, 2013). Data hasil pengukuran yang diperoleh disetiap titik dan waktu pengukuran dihitung tingkat kebisingan rata-ratanya dan ratarata tersebut dipergunakan untuk menghitung tingkat kebisingan pada waktu aktivitas siang hari di depan dan di belakang klaster tanaman. Tingkat kebisingan pada waktu aktivitas siang hari dihitung menggunakan persamaan 1 berikut:

$$
T I_{n}=L S_{n}=10 \log \frac{1}{16}\left\{T_{1} 10^{0,1 . L_{1}}+T_{2} 10^{0,1 . L_{2}}+T_{3} 10^{0,1 . L_{3}}+T_{4} 10^{0,1 . L_{4}}\right\}
$$

Dimana $\mathrm{TI}_{\mathrm{n}}=\mathrm{LS}_{\mathrm{n}}=$ Tingkat kebisingan di depan atau di belakang klaster tanaman pada waktu aktivitas siang hari $(\mathrm{dB}), \mathrm{T}_{1}=$ interval waktu pengukuran yang mewakili pukul 07.00 WIB, $\mathrm{T}_{2}=$ interval waktu pengukuran yang mewakili pukul $10.00 \mathrm{WIB}, \mathrm{T}_{3}=$ interval waktu pengukuran yang mewakili pukul 15.00 WIB, $\mathrm{T}_{4}=$ interval waktu pengukuran yang mewakili pukul 20.00 WIB, $\mathrm{L}_{1}=$ tingkat kebisingan rata-rata pada pengukuran pukul 07.00 WIB, $\mathrm{L}_{2}=$ tingkat kebisingan rata-rata pada pengukuran pukul $10.00 \mathrm{WIB}, \mathrm{L}_{3}=$ tingkat kebisingan rata-rata pada pengukuran pukul $15.00 \mathrm{WIB}$, dan $\mathrm{L}_{4}=$ tingkat kebisingan rata-rata pada pengukuran pukul 20.00 WIB.

Untuk menghitung besar reduksi tingkat kebisingan oleh masing kalster tanaman menggunakan persamaan 2 berikut: 


$$
\Delta T I=T I_{2}-T I_{1}
$$

Dimana $\Delta \mathrm{TI}=$ reduksi tingkat kebisingan $(\mathrm{dB}), \quad \mathrm{TI}_{1}=$ Tingkat kebisingan siang hari $1 \mathrm{~m}$ dari pinggir jalan (di depan klaster), dan $\mathrm{TI}_{2}=$ Tingkat kebisingan siang hari $5 \mathrm{~m}$ di belakang klaster tanaman.

Untuk mengetahui tingkat efektivitas klaster tanaman sebagai penghalang alami untuk mereduksi tingkat kebisingan, data tingkat kebisingan rata-rata untuk aktivitas siang hari dilakukan analsis data menggunakan analisis sidik ragam satu faktorial (Jenis klaster tanaman).

\section{HASIL DAN PEMBAHASAN}

Hasil penelitian pengukuran tingkat kebisingan kendaraan bermotor di Jalan By Pass Alang-Alang Lebar Kota Palembang disajikan dalam Tabel 1 berikut:

Tabel 1. Tingkat kebisingan dan reduksi kebisingan di Jalan Bay Pass Alang-Alang Lebar Kota Palembang

\begin{tabular}{|c|c|c|c|}
\hline \multirow{2}{*}{ Klaster Tanaman } & \multicolumn{2}{|c|}{ Tingkat Kebisingan (dB) } & \multirow{2}{*}{$\begin{array}{c}\text { Reduksi Kebisingan (dB) } \\
\qquad \mathrm{TI}\end{array}$} \\
\hline & $\mathrm{TI}_{1}$ & $\mathrm{Tl}_{2}$ & \\
\hline \multirow{6}{*}{ Bunga Tanjung } & 70,9 & 60,4 & 10,5 \\
\hline & 70,8 & 61,3 & 9,5 \\
\hline & 70,9 & 65 & 5,9 \\
\hline & 70,6 & 66,4 & 4,2 \\
\hline & 70,7 & 66,9 & 3,8 \\
\hline & 70,6 & 67,6 & 3,0 \\
\hline \multirow{6}{*}{ Bungur } & 70,3 & 61,7 & 8,6 \\
\hline & 71,8 & 64,3 & 7,5 \\
\hline & 70,9 & 65,1 & 5,8 \\
\hline & 69,4 & 65,9 & 3,5 \\
\hline & 70,2 & 66,9 & 3,3 \\
\hline & 71,5 & 68,4 & 3,1 \\
\hline \multirow{6}{*}{ Tembesi } & 71,0 & 61,9 & 9,1 \\
\hline & 70,8 & 64,4 & 6,4 \\
\hline & 71,5 & 66,4 & 5,1 \\
\hline & 72,1 & 68,2 & 3,9 \\
\hline & 69,7 & 67,0 & 2,7 \\
\hline & 69,2 & 67,6 & 1,6 \\
\hline \multirow{6}{*}{ Mahoni } & 71,6 & 66,2 & 5,4 \\
\hline & 69,2 & 65,2 & 4,0 \\
\hline & 70,3 & 66,9 & 3,4 \\
\hline & 69,7 & 66,8 & 2,9 \\
\hline & 68,8 & 66,5 & 2,3 \\
\hline & 67,9 & 66,2 & 1,7 \\
\hline \multirow{6}{*}{ Palem } & 71,9 & 66,7 & 5,2 \\
\hline & 71,8 & 67,4 & 4,4 \\
\hline & 70,7 & 66,9 & 3,8 \\
\hline & 70,5 & 67,4 & 3,1 \\
\hline & 69,9 & 67,2 & 2,7 \\
\hline & 70,1 & 68,3 & 1,8 \\
\hline
\end{tabular}

Pada Tabel 1 di atas terlihat bahwa keberadaan klaster tanaman dapat menurunkan tingkat kebisingan yang ditimbulkan oleh kendaraan bermotor. Dari Tabel 1 terlihat bahwa rata-rata reduksi tingkat kebisingan tertinggi oleh klater tanaman bunga tanjung sebesar $6,1 \mathrm{~dB}$, hal ini terjadi karena klaster tanaman tersebut memiliki daun yang rimbun, berdaun kecil dan kaku, membentuk rongga-rongga udara 
antara daun dengan daun maupun antara ranting dengan ranting. Hal ini yang menyebabkan terjadinya refleksi, refraksi, difraksi dan absorpsi suara yang melewati klaster tanaman tersebut, sehingga tingkat kebisingan setelah melewati klaster tanaman tersebut menjadi lebih rendah. Adanya rongga-rongga udara antara cabang-cabang, antara daun dalam satu cabang maupun dengan cabang lain, menyebabkan pemantulan dan pembiasan suara dan bentuk tajuk pohon menyerupai conus menyebabkan terjadinya penyerapan suara (Jumingin dkk, 2016). Disamping itu klaster tanaman bunga tanjung memiliki ukuran yang lebih tebal dibandingkan dengan klaster tanaman yang lainnya. Berkurangnya nilai tingkat kebisingan di jalan raya Pekanbaru-Bangkinang oleh karena adanya pohon sebagai bahan penghalang/penyerap (Azura dkk, 2015).

Rata-rata reduksi tingkat kebisingan tertinggi kedua adalah oleh klaster tanaman bungur sebesar 5,3dB. Tanaman bungur memiliki daun yang lebar dan lentur, sehingga suara yang datang melewatinya akan mengalami Refleksi dan refraksi oleh daun, ranting, dan batang. Sehingga suara yang sampai terukur dibelakang klaster menjadi lebih rendah dibandingkan di depan klaster tanaman. Rata-rata reduksi tingkat kebisingan ketiga adalah oleh klaster tanaman tembesi sebesar 4,8 dB. Tanaman tembesi mempunyai tajuk yang lebar, daun yang kecil-kecil dan ranting yang lebih rapat dari 4 klaster tanaman lain yang ada. Dengan lebar tajuk yang besar, suhu udara dibawahnya terasa lebih sejuk. Semakin rendah suhu udara maka cepat rambat bunyi semakin cepat.

Rata-rata reduksi tingkat kebisingan tertinggi keempat adalah oleh klaster tanaman palem sebesar 3,5dB. Tanaman palem ditanam dengan jarak yang lebih rapat dibandingkan keempat klaster yang ada, sehingga suara yang datang akan mengalami refleksi dan refraksi oleh batang. Oleh karena adanya peristiwa tersebut, energi suara yang diterima di belakang klaster tanaman berkurang. Model jendela jalusi mampu mereduksi lebih baik dari model jendela casement dan jendela top-hung (Mediastika, 2005).

Rata-rata reduksi tingkat kebisingan terendah oleh klaster tanaman mahoni. Tanaman mahoni mempunyai batang pokok ke arah vertikal, daun yang kecil dan ke arah horizontal, sehingga masih besar tingkat kebisingan yang sampai ke belakang klaster tanaman. Pohon mahoni memiliki batang pokok yang monopodial, cabang tumbuh secara ortotropik, tangkai daun spiral, daun kecil, dan arah tangkai daun ke arah horizontal tegak lurus dengan arah cabang (Jumingin dkk, 2016).

\section{Hubungan Klaster Tanaman dengan Reduksi Tingkat Kebisingan}

Untuk mengetahui hubungan klaster tanaman dengan reduksi tingkat kebisingan dilakukan analisis sidik ragam yang disajikan dalam Tabel 2 berikut:

Tabel 2. Analisis Sidik Ragam Klaster Tanaman dengan Reduksi Tingkat Kebisingan

\begin{tabular}{lccccc}
\hline \multirow{2}{*}{ Klaster tanaman } & \multicolumn{5}{c}{ Taraf Signifikansi $(\alpha=5 \%)$} \\
\cline { 2 - 6 } & Bunga Tanjung & Bungur & Tembesi & Mahoni & Palem \\
\hline Bunga Tanjung & - & 0,525 & 0,315 & $0,039^{*}$ & 0,055 \\
Bungur & 0,525 & - & 0,708 & 0,138 & 0,184 \\
Tembesi & 0,315 & 0,708 & - & 0,261 & 0,333 \\
Mahoni & $0,039^{*}$ & 0,138 & 0,261 & - & 0,871 \\
Palem & 0,055 & 0,184 & 0,333 & 0,871 & - \\
\hline
\end{tabular}

Dari Tabel 2 terlihat bahwa reduksi tingkat kebisingan oleh klaster tanaman bunga tanjung dengan klaster tanaman mahoni berbeda nyata dengan nilai signifikansi sebesar 0,039. Sedangkan reduksi tingkat kebisingan oleh klaster 
tanaman bunga tanjung dengan klaster tanaman bungur, tembesi dan palem berbeda tidak nyata dengan nilai signifikansi lebih dari 0,05. Reduksi tingkat kebisingan oleh klaster tanaman bungur dengan klaster tanaman bunga tanjung, tembesi, mahoni dan palem berbeda tidak nyata dengan nilai signifikansi lebih dari 0,05. Reduksi tingkat kebisingan oleh klaster tanaman tembesi dengan klaster tanaman bunga tanjung, bungur, dan palem berbeda tidak nyata dengan nilai signifikansi lebih dari

\section{KESIMPULAN}

Klaster tanaman yang paling efektif untuk mereduksi tingkat kebisingan

\section{Ucapan Terima Kasih:}

Penulis mengucapkan terima kasih kepada DRPM Direktorat Jenderal Riset dan Pengembangan Kemenristekdikti yang telah mendanai kegiatan penelitian ini untuk anggaran pendanaan penelitian tahun 2019.

\section{DAFTAR PUSTAKA}

Azura, Erwin, \& Defrianto. (2015). Analisa Pengaruh Vegetasi terhadap Tingkat Kebisingan di Sepanjang Jalan Raya PekanbaruBangkinang," JOM FMIPA, 2(1), 32-40.

Cobani, E., \& Aleksi, L. (2012). Application of Tree Barrier as Mitigation Measures for Noise Polution Road Tirana Albania. Journal International Applications \& Science, 7(2), 427-431.

Jumingin, Dahlan, Z., \& Setyabudidaya, D. (2016). Effect of Architectural Tree Model to the Noise Level of Motor Vehicle on Demang Lebar Daun Street Palembang. Jurnal Biovalentia: Biological Research Journal, 2(2), 1-8.

Kalansuriya, C. M., Panila, A. S., \& Sonnadara, D. U. J. (2009). Effect
0,05 . Reduksi tingkat kebisingan oleh klaster tanaman mahoni dengan klaster tanaman bunga tanjung berbeda nyata dengan signifikansi 0,039, sedangkan reduksi tingkat kebisingan oleh klaster tanaman mahoni dengan klaster tanaman bungur, tembesi dan palem berbeda tidak nyata dengan nilai signifikansi lebih dari 0,05 . Reduksi tingkat kebisingan oleh klaster tanaman palem dengan klaster tanaman bunga tanjung, bungur, tembesi, dan palem berbeda tidak nyata dengan nilai signifikansi lebih dari 0,05 .

kendaraan bermotor dalam penelitian adalah klaster tanaman Bunga Tanjung.

of Roadside Vegetation on the Reduction of Traffic Noise Level. Proceeding of the Technical Sessions, 25., Institute of Physics Sri Lanka. 1-6.

Keputusan Menteri Lingkungan Hidup, Nomor 48. (1996). Baku Mutu Kebisingan.

Mediastika, C. E. (2005). Potensi Jendela dalam Meminimalkan Intrusi Kebisingan: Sebuah Studi Awal. Jurnal Dimensi Teknik Arsitektur, 33(1), 165-171.

Nurmaningsih, D. R., Kusmiyati, \& Riyanto, A. Sr. (2014). Pengaruh Aktivitas Kendaraan Bermotor terhadap Kebisingan di Kawasan Pendidikan Sekolah Menengah Pertama Pangudi Luhur Surakarta. Jurnal Ilmu-Ilmu Teknik-Sistem, 10(2), 62-69.

Satoto, H. F. (2018). Analisa Kebisingan Akibat Aktifitas Transportasi pada Kawasan Pemukiman Jalan Sutorejo-Mulyorejo Surabaya. Jurnal Teknik Industri Heuristic, 15(1), 49-62.

Setiawan, A. (2014). Pengaruh Kecepatan dan Jumlah Kendaraan terhadap Kebisingan (Studi Kasus Kawasan Kos Mahasiswa di Jalan Raya Prabumulih-Palembang KM 
32 Indralaya Sumatera Selatan). Jurnal Teknik Sipil dan Lingkungan, 2(4), 209-614.

Tyagi, V., Kumar, K., \& Jain, V. K. (2013). Road Traffic Noise Attenuation by Vegetation Belts at Some Sites in the Tarai Region of India New Delhi India. Journal Archives of Accoustics, 38(3), 389-395.

Wardika, I. K., Suparsa, I. G. P., \& Priyantha, D. M. W. (2012). Analisis Kebisingan Kebisingan
Lalu Lintas pada Ruas Jalan Arteri (Studi Kasus Jalan Prof. DR. IB. Mantra pada KM $15 \mathrm{~s} / \mathrm{d}$ KM 16). Jurnal Ilmiah Elektronik Infrastruktur Teknik Sipil, 1(1), XV1-XV8.

Werdiningsih, H. (2007). Kajian Penggunaan Tanaman sebagai Alternatif Pagar Rumah. Jurnal Ilmiah Perancangan Kota dan Pemukiman ENCLOSURE, 6(1), 32-39. 